\title{
Stabilization of Ash and Slag from Combustion of Medical Waste in the Geopolymers Matrix
}

\author{
Dariusz Mierzwiński ${ }^{1,}{ }^{*}$, Michał Łach ${ }^{1}$, Janusz Mikuła ${ }^{1}$, and Marcin Goły ${ }^{2}$ \\ ${ }^{1}$ Cracow University of Technology, Faculty of Mechanical Engineering, Institute of Materials \\ Engineering, 37 Jana Pawła II Av., 31-864 Cracow, Poland \\ ${ }^{2}$ AGH University of Science and Technology, Faculty of Metals Engineering and Industrial Computer \\ Science, Department of Physical Metallurgy \& Powder Metallurgy, 30 Mickiewicza Av., 30-059 \\ Cracow, Poland
}

\begin{abstract}
This paper regards the possibility of using geopolymer matrix to immobilize heavy metals present in ash and slag from combustion of medical waste. In the related research one used the fly ash from coal combustion in one Polish CHP plant and the waste from two Polish incineration plants. It was studied if the above-named waste materials are useful in the process of alkali-activation. Therefore, two sets of geopolymer mixtures were prepared containing 60 and $50 \%$ of ash and slag from the combustion of medical waste. The remaining content was fly ash from coal combustion. The alkali-activation was conducted by means of $14 \mathrm{M}$ solution of $\mathrm{NaOH}$ and sodium water glass. The samples, whose dimensions were in accordance with the EN 206-1 norm, were subjected to $75^{\circ} \mathrm{C}$ for $24 \mathrm{~h}$. According to the results, the geopolymer matrix is able to immobilize heavy metals and retain compressive strength resembling that of $\mathrm{C} 8 / 10$ type concrete.
\end{abstract}

\section{Introduction}

In the last decade the production of medical waste significantly increased [1]. They are rendered harmless mainly by means of combustion, for that process destroys the pathogens and decreases the volume and weight of the waste. However, it results in the in-crease of the amount of ash and slag containing toxic substances and heavy metals [2,3]. Stabilisation or solidification is one of waste processing methods that have application to a wide range of industrial waste [4]. Solidification of alkali-activated fly ash is particularly effective in immobilization of heavy metals [5]. Fly ash from coal combustion is very often used as puzzolanic material able to replace the traditional Portland cement. It has, nevertheless, high content of water-soluble calcium and sulphur oxides, which hinders its potential applications $[6,7]$. Despite that fact, fly ash and slag may be used as precursors for the production of geopolymers $[8,9]$.

*Corresponding author: dariusz.mierzwinski@mech.pk.edu.pl 


\section{Materials and methods}

\subsection{Materials}

The conducted analysis pertained to the samples of ash and slag from two Polish incineration plants utilizing, among others, medical waste. The by-products from these plants are classified as slag and bottom ash not comprising hazardous substances labeled as 1901 12. The samples were taken in winter and labeled as WA and WB. In order to prepare the geopolymer mixture the fly ash from a Polish CHP plant was used (sample labeled as FA). The oxide compositions of the particular samples are presented in Table 1.

Table 1. Chemical compositions of the waste (WA, WB) and fly ash (FA)

\begin{tabular}{|l|l|c|c|c|c|c|c|c|c|c|}
\hline & $\mathrm{SiO}_{2}$ & $\mathrm{Al}_{2} \mathrm{O}_{3}$ & $\mathrm{Fe}_{2} \mathrm{O}_{3}$ & $\mathrm{Na}_{2} \mathrm{O}$ & $\mathrm{K}_{2} \mathbf{O}$ & $\mathbf{C a O}$ & $\mathbf{M g O}$ & $\mathrm{TiO}_{2}$ & $\mathbf{S O}_{3}$ & $\mathbf{P}_{2} \mathrm{O}_{5}$ \\
\hline WA & 18.67 & 10.27 & 16.94 & 3.45 & 0.36 & 15.54 & 2.35 & 10.52 & 4.29 & 1.48 \\
\hline WB & 14.55 & 6.97 & 7.73 & 5.36 & 1.13 & 20.86 & 1.96 & 7.49 & 5.66 & 1.76 \\
\hline FA & 50.50 & 25.30 & 13.90 & 1.08 & 3.16 & 3.60 & 2.20 & 1.00 & 0.42 & \\
\hline
\end{tabular}

\subsection{Characterization methods}

\subsubsection{Particle size analysis}

In the case of the samples WA and WB particle size analysis was conducted by means of screening method in accordance with the norm EN 933-1. The used sieves were in conformity with the norm EN 932-5. The analysis was carried out three times. The difference between the sum of masses of all the particle grades and the mass of the analyzed sample should have not exceeded $2 \%$.

\subsubsection{Properties of materials}

In order to determine the properties of the samples WA and WB the measurements were conducted regarding: density, specific surface area, humidity, fineness and loss-on-ignition. Density was measured according to the methodology specified in the norm EN 451-2 by means of helium pycnometer Pycnomatic ATC that allows for determining the density of solid, porous and loose samples. The density of each sample was measured three times. The specific surface area was measured according to the methodology specified in the norm EN 196-6 by means of Blaine's apparatus. The samples were dried to constant mass in a drier at $(105 \pm 5)^{\circ} \mathrm{C}$. The permeability of each sample was determined three times.

\subsubsection{Dioxins and furans analysis}

The combustion of chemical substances containing particles of chlorine results in the production of dioxins and furans i.e. chemical compounds particularly hazardous for the environment. Therefore, the analyzed ash and slag were subjected to tests to detect the presence of dioxins and furans and to determine their toxic equivalency factor (TEQ). 


\subsubsection{XRF analysis}

Before the samples WA and WB were subjected to XRF examination, they have been made uniform by milling. Such a procedure is necessary to determine the composition of the sample by means of XRF examination. The chemical composition was determined by virtue of the fluorescent X-Ray spectrometer S4 Explorer with wavelength dispersion (WDXRF).

\subsection{Preparation of geopolymer}

To obtain geopolymer mortar two series of mixtures were prepared. One of them contained $60 \%$ of WA waste and $40 \%$ of fly ash (FA) whereas the other one comprised $50 \%$ of WB waste and $50 \%$ of fly ash (FA). They were labeled as WA60FA40 and WB50FA50, respectively. Both samples contained $\mathrm{NaOH}$. Including the amount of $\mathrm{Si}$ and $\mathrm{Na}$ from $\mathrm{NaOH}$ and water glass [1], the sample WA60FA40 had the following molar ratio of the contained oxides: $\mathrm{Na}_{2} \mathrm{O} / \mathrm{SiO}_{2}=0.08 ; \mathrm{SiO}_{2} / \mathrm{Al}_{2} \mathrm{O}_{3}=3.27 ; \mathrm{Na}_{2} \mathrm{O} / \mathrm{Al}_{2} \mathrm{O}_{3}=0.25$.

The sample WB50FA50 had the following molar ratio of the oxides it contained: $\mathrm{Na}_{2} \mathrm{O} / \mathrm{SiO}_{2}=0.10, \mathrm{SiO}_{2} / \mathrm{Al}_{2} \mathrm{O}_{3}=3.42$ and $\mathrm{Na}_{2} \mathrm{O} / \mathrm{Al}_{2} \mathrm{O}_{3}=0.33$. The samples, whose dimensions were $150 \times 150 \times 150$ were subjected to alkali activation at $75^{\circ} \mathrm{C}$ for $24 \mathrm{~h}$ [11].

\subsubsection{Compressive strength test}

After 28 days of curing the cubic samples were subjected to compressive strength tests in conformity with the norm EN 12390-4. The tests were conducted once again after 150 days of curing in order to determine the impact of curing on the mechanical properties of the samples.

\subsubsection{Leachable concentrations}

The samples in the delivery condition and samples which underwent geopolymerization were examined in terms of their leachablity. The latter samples were tested after 28 days and 150 days of curing so that to prove that the matrix made from alkali-activated fly ash is suitable for disposal of the analyzed hazardous waste in the dedicated refuse collection facilities. Thus, the measurements were carried out according to the norms EN 12457-4 and EN 15216.

\section{Results and discussion}

\subsection{Characterization of source materials}

\subsubsection{Microstructural study}

The particles presented in Fig. 1a) are very diverse in terms of their shape, structure and size, and it may be due to the presence of many phases. Sample WA contains porous particles and its structure is heterogeneous. In the case of WB sample, presented in Fig. 1b) one can see big agglomerates made of long fibers heading for various directions as well as oval particles and grains of irregular shape. The structure of those agglomerates is two-phase and heterogeneous Table 2 and Table 3 present the properties of the analyzed waste samples. 

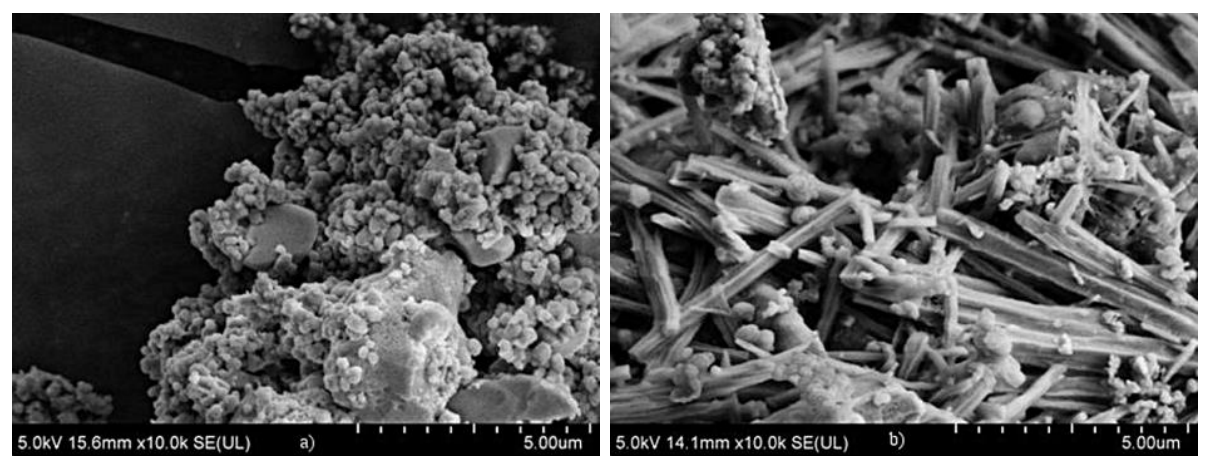

Fig. 1. SEM micrograph of waste i the delivery condition (a) WA, (b) WB

\subsubsection{Particle size analysis}

According to the particle size analysis of the examined ash and slag (Table 2), the analyzed materials were very heterogeneous. Up to $0.4 \mathrm{~mm}$ of the equivalent diameter of the sieve they contained up to $50 \%$ of large particles. Therefore, they required milling before some tests. Milling was applied to the fraction that did not pass through the mesh whose diameter was $0.4 \mathrm{~mm}$.

Table 2 Particle size analysis

\begin{tabular}{|c|c|c|c|c|c|c|c|c|c|c|c|}
\hline $\begin{array}{c}\mathbf{d} \\
{[\mathbf{m m}]}\end{array}$ & $\mathbf{> 1 . 6}$ & $\mathbf{0 . 8}$ & $\mathbf{0 . 6 3}$ & $\mathbf{0 . 4}$ & $\mathbf{0 . 3 2}$ & $\mathbf{0 . 2}$ & $\mathbf{0 . 1 6}$ & $\mathbf{0 . 1}$ & $\mathbf{0 . 0 7 1}$ & $\mathbf{0 . 0 5 6}$ & \begin{tabular}{c}
$\mathbf{0 . 0 5 6}$ \\
\hline WA
\end{tabular} \\
23.33 & 16.49 & 4.25 & 11.07 & 4.57 & 10.46 & 3.45 & 6.88 & 4.46 & 3.52 & 11.56 \\
\hline WB & 34.29 & 15.26 & 3.45 & 9.94 & 4.82 & 9.83 & 3.68 & 8.86 & 5.38 & 3.07 & 1.41 \\
\hline
\end{tabular}

\subsubsection{Properties of materials}

The examination of the properties of the waste materials pertained to the unmilled materials in the delivery condition. Table 3 presents the overall results for both tested materials. There were no significant differences with regard to their density, fineness and specific surface area. However, the loss on ignition was much higher in the case of WB sample, because, in comparison to WA, its humidity was also substantially higher.

Table 3. Properties of the waste in the delivery condition

\begin{tabular}{|c|c|c|c|c|c|}
\hline & $\begin{array}{c}\text { Specific density } \\
{\left[\mathbf{k g} / \mathbf{m}^{3}\right]}\end{array}$ & Fineness [\%] & $\begin{array}{c}\text { Specific surface } \\
\text { area }\left[\mathbf{c m}^{2} / \mathbf{g}\right]\end{array}$ & Humidity [\%] & $\begin{array}{c}\text { Loss on } \\
\text { ignition }\end{array}$ \\
\hline WA & $3.161 \pm 0.034$ & $87.738 \pm 1.746$ & $753.65 \pm 21.16$ & $7.584 \pm 0.131$ & 6.04 \\
\hline WB & $2.487 \pm 0.205$ & $81.872 \pm 1.551$ & $726.04 \pm 37.80$ & $15.706 \pm 0.340$ & 17.18 \\
\hline
\end{tabular}




\subsubsection{Dioxins and furans}

Table 4. Dioxin/furan content in the wastes WA and WB

\begin{tabular}{|l|c|c|}
\hline \multirow{2}{*}{ Dioxin/furan identity } & \multicolumn{2}{|c|}{ Dioxin/furan content [ng/g] } \\
\cline { 2 - 3 } & WA & WB \\
\hline $2,3,7,8-\mathrm{TeCDD}$ & 0.0070 & 0.1300 \\
\hline $1,2,3,7,8-\mathrm{PeCDD}$ & 0.0060 & 0.2000 \\
\hline $1,2,3,4,7,8-\mathrm{HxCDD}$ & 0.0041 & 0.0320 \\
\hline $1,2,3,6,7,8-\mathrm{HxCDD}$ & 0.0058 & 0.0330 \\
\hline $1,2,3,7,8,9-\mathrm{HxCDD}$ & 0.0063 & 0.0480 \\
\hline $1,2,3,4,6,7,8-\mathrm{HpCDD}$ & 0.0067 & 0.0130 \\
\hline OCDD & 0.0046 & 0.0045 \\
\hline $2,3,7,8-\mathrm{TeCDF}$ & 0.0030 & 0.0100 \\
\hline $1,2,3,7,8-\mathrm{PeCDF}$ & 0.0060 & 0.0500 \\
\hline $2,3,4,7,8-\mathrm{PeCDF}$ & 0.0900 & 0.7000 \\
\hline $1,2,3,4,7,8-\mathrm{HxCDF}$ & 0.0230 & 0.2900 \\
\hline $1,2,3,6,7,8-\mathrm{HxCDF}$ & 0.0290 & 0.3000 \\
\hline $1,2,3,7,8,9-\mathrm{HxCDF}$ & 0.0120 & 0.0100 \\
\hline $2,3,4,6,7,8-\mathrm{HxCDF}$ & 0.0550 & 0.2300 \\
\hline $1,2,3,4,6,7,8-\mathrm{HpCDF}$ & 0.0052 & 0.0110 \\
\hline $1,2,3,4,7,8,9-\mathrm{HpCDF}$ & 0.0260 & 0.2000 \\
\hline OCDF & 0.0110 & 0.0018 \\
\hline
\end{tabular}

The sum of dioxins/furans (I-PCDD/F-TEQ) presented in Table 4 was $0.30 \pm 0.078 \mathrm{ng} / \mathrm{g}$ in the case of WA waste and $2.3 \pm 0.59 \mathrm{ng} / \mathrm{g}$ in the case of WB waste. The results were expressed in accordance with the 1998 I-TEF list. All results were below the maximum acceptable TEQ level. According to the recent scholarship [2] the levels of I-TEQ determined in the furnace ash from the modern incineration plants are similar to those found in urban and industrial soils. Bottom ash contains $<0.001-0.01 \mathrm{ng} / \mathrm{g}$ of dioxins and furans whereas boiler ash contains $0.02-0.5 \mathrm{ng} / \mathrm{g}$, and ash from the filter $0.2-10 \mathrm{ng} / \mathrm{g}$. That may indicate the origin of the examined ash.

\subsubsection{XRF analysis}

Table 5 presents the concentration of the chemical elements [wt $\%$ ] in WA and WB waste (according to the XRF examination). 
Table 5. Concentration of elements [\% wt]

\begin{tabular}{|c|c|c|c|c|c|c|c|c|c|c|c|c|c|}
\hline & $\mathbf{A l}$ & $\mathbf{B a}$ & $\mathbf{C a}$ & $\mathbf{C l}$ & $\mathbf{C u}$ & $\mathbf{F e}$ & $\mathbf{K}$ & $\mathbf{M g}$ & $\mathbf{N a}$ & $\mathbf{S}$ & $\mathbf{S i}$ & $\mathbf{T i}$ & $\mathbf{Z n}$ \\
\hline WA & 3.72 & 7.18 & 11.84 & 1.49 & 0.40 & 14.20 & 0.37 & 0.75 & 1.10 & 0.73 & 5.65 & 5.84 & 2.11 \\
\hline WB & 1.37 & 1.13 & 18.56 & 6.40 & 0.53 & 4.32 & 0.40 & 0.35 & 2.20 & 0.99 & 1.87 & 2.72 & 1.59 \\
\hline
\end{tabular}

\subsubsection{Compressive strength}

Table 6 presents the results of the compressive strength tests of the obtained geopolymers. According to the norm EN 206-1, samples WA60FA40 and WB50FA50 were slightly below the $\mathrm{C} 8 / 10$ class of compressive strength for typical concrete. However, in the course of time their compressive strength increased slightly and such relationship between its value and curing period suggests that there is even more potential for a further increase $[13,14]$.

Table 6. Compressive strength of cubic samples, $f_{c k, c u b e}\left[\mathrm{~N} / \mathrm{mm}^{2}\right]$

\begin{tabular}{|c|c|c|}
\hline & 28 days & 150 days \\
\hline WA60FA40 & $6.75 \pm 0.89$ & $7.91 \pm 0.53$ \\
\hline WB50FA50 & $8.81 \pm 0.97$ & $9.31 \pm 0.89$ \\
\hline
\end{tabular}

\subsubsection{Leachable concentrations}

Table 7 presents the leachable concentrations for WA and WB waste in the delivery condition and for the alkali-activated samples WA60FA40 and WB50FA50 after 28 days and 150 days of curing. In the case of all alkali-activated samples, the leachable concentrations of $\mathrm{Ba}, \mathrm{Cd}, \mathrm{Cr}, \mathrm{Cu}, \mathrm{Ni}, \mathrm{Pb}, \mathrm{Sb}$ and $\mathrm{Zn}$ were either below or slightly above the limit of detection.

Regarding As and Se, their leaching was much more discernible in the alkali-activated samples [15]. In WA and WB waste those particular elements were below the detection limit and their occurrence after 28 days and 150 days was directly connected with the sort of theused fly ash from coal combustion. The leachable concentration of As, Se, Mo and $\mathrm{SO}_{4}{ }^{2-}$ depends on the $\mathrm{pH}$ of the examined material $[16,17]$. The lower the $\mathrm{pH}$ was, the less As and Se was leaching from the samples WA60FA40 and WB50FA50. The described the method of precipitation of arsenic with lead [18], but in the examined materials the amount of $\mathrm{Pb}$ was below the limit of detection. This trace content of lead might, nevertheless, affect the leaking of chorine ions $[18,19]$. In the presence of $\mathrm{Pb}^{+2}, \mathrm{PO}_{4}^{-3}$ and $\mathrm{Cl}^{-}$ the immobilization process may result in the synthesis of pyromorphite i.e. crystalline lead chlorophosphate $\mathrm{Pb}_{5}\left(\mathrm{PO}_{4}\right)_{3} \mathrm{Cl}$. This mineral is isostructural to mimetite that has similar properties as it crystallizes easily, has high specific gravity and is very environmentally durable $[20,21]$. In the case of sample WB50FA50 even the decrease of $\mathrm{pH}$ did not prevented it from the increasing leaching of ions of $\mathrm{SO}_{4}{ }^{2-}$.

As for molybdenum, its presence was determined in the delivered material and its concentration resulting from leaching from the alkali-activated samples was high. That issue was de-scribed in some of the recent scholarly papers [13, 22-24]. The content of molybdenum was lower in the samples curing for 150 days. 
Table 7. Leachable concentrations $[\mathrm{mg} / \mathrm{kg}]$ of hazardous components in samples

\begin{tabular}{|c|c|c|c|c|c|c|}
\hline & \multirow{2}{*}{ WA } & \multirow{2}{*}{ WB } & \multicolumn{2}{|c|}{ WA60FA40 } & \multicolumn{2}{|c|}{ WB50FA50 } \\
\hline & & & 28 days & 150 days & 28 days & 150 days \\
\hline As & $<0.5$ & $<0.5$ & 104.00 & 51.80 & 12.97 & 11.60 \\
\hline $\mathrm{Ba}$ & 1.56 & 7.88 & 1.64 & $<0.5$ & $<0.5$ & $<0.5$ \\
\hline $\mathrm{Cd}$ & $<1$ & $<1$ & $<1$ & $<1$ & $<1$ & $<1$ \\
\hline $\mathrm{Cl}$ & $7,737.4$ & $21,830.0$ & $7,780.0$ & $6,710.0$ & $23,400.0$ & $33,270.0$ \\
\hline $\mathrm{Cr}$ & $<1$ & $<1$ & $<1$ & $<1$ & 1.71 & $<1$ \\
\hline $\mathrm{Cu}$ & $<1$ & $<1$ & 1.96 & $<1$ & $<1$ & $<1$ \\
\hline Mo & 10.73 & 6.78 & 40.80 & 20.00 & 9.34 & 8.25 \\
\hline $\mathrm{Ni}$ & $<1$ & $<1$ & $<1$ & $<1$ & $<1$ & $<1$ \\
\hline $\mathrm{Pb}$ & $<1$ & $<1$ & $<1$ & $<1$ & $<1$ & $<1$ \\
\hline $\mathrm{Sb}$ & $<0.5$ & $<0.5$ & 1.7 & $<0.5$ & $<0.5$ & $<0.5$ \\
\hline $\mathrm{Se}$ & $<0.5$ & $<0.5$ & 10.9 & 5.94 & 2.03 & 2.35 \\
\hline $\mathrm{SO}_{4}{ }^{2-}$ & $7,511.2$ & 8,280 & 8,380 & 7,990 & 22,370 & 35,160 \\
\hline $\mathrm{Zn}$ & $<1$ & $<1$ & 1.37 & $<1$ & $<1$ & $<1$ \\
\hline $\mathrm{pH}$ & 9.3 & 9.8 & 11.4 & 10.8 & 11.6 & 10.0 \\
\hline
\end{tabular}

\section{Conclusions}

In the case of the alkali-activated samples the extended period of curing positively affected the immobilization of heavy metals. Together with the use of the properly chosen fly ash from coal combustion, it may decrease the leachability of the obtained materials. However, the examination concerning leachability was applied to loose materials. Geopolymers synthesized from solid fly ash may be almost fully resistant to leaching of heavy metals (the exception will be only their surface directly exposed to atmospheric conditions). During the preproduction, preceding the geopolymerization process, raw waste resources may be washed in order to remove a part of chlorine compounds, but it may decrease the compressive strength of the final materials [25].

The research was conducted owing to the financial support by the National Center for Research and Development and the National Fund for Environmental Protection and Water Management as a part of the EU programme, within the project "Innovative and Environmentally Safe Methods of Immobilization of Dust, Slag and Ash from the Municipal Waste Incinerators and other Thermal Processes" no. GEKON1/O5/213240/35/2015. 


\section{References}

1 A. Rajor, G. Kunal, International Journal Of Geology 1, 2277-2081, (2011)

2 H. Jung, T. Matsuto, N. Tanaka, T. Okada, Waste Manage 24, 381-391, (2004)

3 I. Kougemitrou, A. Godelitsas, C. Tsabaris, V. Stathopoulos, A. Papandreou, P. Gamaletsos, G. Economou, D. Papadopoulos, J Hazard Mater 187, 421-432, (2011)

4 X. Li, Q. Chen, Y. Zhou, M. Tyrer, Y. Yu, Waste Manage 34, 2494-2504, (2014)

5 K. Tzanakos, A. Mimilidou, K. Anastasiadou, A. Stratakis, E. Gidarakos, Waste Manage 34, 1823-1828, (2014)

6 P. Chindaprasirt, C. Jaturapitakkul, T. Sinsiri, Constr Build Mater 21, 1534-1541, (2007)

7 P. Chindaprasirt, U. Rattanasak, Waste Manage 30, 667-672, (2010)

8 P. Chindaprasirt, T. Chareerat, V. Sirivivatnanon, Cement and Concrete Composites 29, 224-229, (2007)

9 P. Chindaprasirt, C. Jaturapitakkul, W. Chalee, U. Rattanasak, Waste Manage 29, 539-543, (2009)

10 J. Davidovits, J Therm Anal Calorim 37, 1633-1656, (1991)

11 Lancellotti, C. Ponzoni, L. Barbieri, C. Leonelli, Waste Manage 33, 1740-1749, (2013)

12 J. Vehlow, Vtt Symp, 151-176, (2002)

13 M. B. Ogundiran, H. W. Nugteren, G. J. Witkamp, J Hazard Mater 248, 29-36, (2013)

14 L. Zheng, C. Wang, W. Wang, Y. Shi, X. Gao, Waste Manage 31, 311-317, (2011)

15 E. Diaz-Loya, E. N. Allouche, S. Eklund, A. R. Joshi, K. Kupwade-Patil, Waste Manage 32, 1521-1527, (2012)

16 H. A. van der Sloot, Cement Concrete Res 30, 1079-1096, (2000)

17 A. Król, Opole University of Technology, (2012)

18 J. V. Bothe, P. W. Brown, Enviromental Science \& Technology 33, 3806-3811, (1999)

19 M. C. F. Magalhães, Pure Appl Chem 74, 1843-1850, (2002)

20 M. Manecki, P. A. Maurice, S. J. Traina, Soil Sci 165, 920-933, (2000)

21 Q. Y. Ma, S. J. Traina, T. J. Logan, J. A. Ryan, Environmental Science and Technology 27, 1803-1810, (1993).

22 J. Yliniemi, J. Pesonen, M. Tiainen, M. Illikainen, Waste Manage 43, 273-282, (2015)

23 S. Ahmari, L. Zhang, Constr Build Mater 44, 743-750, (2013)

24 E. Álvarez-Ayuso, X. Querol, F. Plana, A. Alastuey, N. Moreno, M. Izquierdo, O. Font, T. Moreno, S. Diez, E. Vázquez, M. Barra, J Hazard Mater 154, 175-183, (2008)

25 X. Wang, A. Li, Z. Zhang, Procedia Environ Sci 31, 440-446, (2016) 